\title{
O direito de ler
}

Graves, M.F.; Broek, P. Vanden \& Taylor, M. (orgs.) (1996). The first R: every child's righ read. New York: Teachers College. xix $+296 p$.

Todas as crianças têm o direito de ler, valer dizer, o direito à leitura deve ser assegurado a todos. Sendo a leitura instrumento básico para a informação e o saber tem que ser garantido a todos a aquisição desta habilidade, garantindo bases para o desenvolvimento pessoal e da própria sociedade. Nestas circunstâncias é particularmente relevante contar com uma obra aqui resenhada que enfoca este direito de forma abrangente.

Além da Introdução o livro é composto por nove capítulos e por uma conclusão. A Introdução leva a assinatura de Graves que começa por retomar questões sobre a alfabetização de todas as crianças, formuladas em livros e artigos, em busca de reduzir o abismo entre o que a escola faz e o que ela deveria fazer (Lei de Goodlad) no que concerne à alfabetização. A despeito dos esforços desenvolvidos, muitas questões permanecem em aberto, “a despeito dos professores adotarem os enfoques instrucionais contemporâneos, altamente recomendados, os resultados mostram que somente $25 \%$ dos alunos da $4^{\text {a }}$ série testados mostram uma base acadêmica sólida e somente $2 \%$ do $12^{\circ}$ grau mostraram desempenho superior” (p.xi). Certamente há muito por fazer além de conseguir fornecer escolas para todas as crianças. Continua com uma breve apresentação dos autores e de seus capítulos.

Boyer (1996) responde pelo primeiro capítulo que trata da relação alfabetização e aprendizagem. A linguagem é a mais essencial de nossas funções sociais e, portanto, todas as suas formas, inclusive a leitura são imprescindíveis e merecem especial atenção. Sua argumentação sobre a relevância para as pessoas e para os países permite-lhe concluir o capítulo de uma maneira muito expressiva: "Claramente, a tarefa mais urgente que nossa geração confronta agora é assegurar alfabetização, não apenas para os mais privilegiados, mas, como o título e tema deste livro nos diz, para todas as crianças”. (p.l)

A primeira parte do livro tem por título: As rotas da alfabetização e engloba dois capítulos e um adendo que consiste em uma resposta aos capítulos. O primeiro capítulo desta parte enfoca o criar e o manter o amor pela literatura mediante o desenvolvimento da capacidade para lê-la. É da autoria de Hiebert que faz uma revisão da literatura e aponta para a carência de pesquisas mas que já se pode contar com estratégias pesquisadas quanto a sua eficiência. Relata ainda os resultados obtidos em um projeto. No terceiro capítulo Perfetti e Zhang tratam do que significa aprender a ler, destacando sobre o que está aprendendo e com êxito. O primeiro autor faz uma autobiografia comentada de como se tomou leitor. Destacam a importância de aprender como o sistema de escrita funciona e os princípios do alfabeto, tomando como termos de comparação o aprender o inglês e o chinês, com base em pesquisa realizada em co-autoria. Concluem que é fundamental saber o que significa para a criança aprender seu sistema de escrita para entender como adquire as habilidades de leitura.

A resposta a estes dois autores foi escrita por Taylor que destaca que ambos permitem olhar a questão de fora da própria cultura e que este distanciamento é bom para o próprio conhecimento.

A Segunda parte da obra trata de mudanças no currículo e no discurso em sala de aula. No 
capítulo e uma equipe liderada por Allington enfoca o currículo baseado na literatura usado em escolas muito pobres. Recupera parte da matéria publicada sob o assunto e toma como referência o uso desta modalidade de currículo em seis escolas, fornecendo uma boa perspectiva do trabalho realizado e sobre pesquisas a serem feitas. O segundo capítulo desta parte é escrito por McKeown, Beck e Sandora e trata de um tema que vem merecendo crescente atenção de pesquisadores: o uso de questões no processo ensino-aprendizagem. No capítulo é enfocado o fazer questões ao autor como forma de dar significado ao discurso em sala de aula, forma de fazer o aluno pensar e responder ao texto.

Desta feita, a resposta coube a Samuels que destaca o esforço dos docentes-pesquisadores no sentido de mudar as aulas de leitura. Faz também uma retrospectiva histórica do ensino de leitura desde o período colonial, lembra o começo do impacto da psicologia no final do século passado, do behaviorismo desde o começo deste século, pelo cognitivismo até as discussões mais recentes com ênfase no que ocorre realmente em sala de aula.

Os processos fonológicos e a construção de significados é enfocada na terceira parte também composto por dois capítulos e uma resposta. Torgesen e Hecht assinam o capítulo 6 e enfocam a prevenção e a remediação de problemas na leitura de estudantes especiais através da manipulação das variáveis do treino tais como ensino individualizado e trabalho com os aspectos fonológicos. O capítulo seguinte (Trovasso \& Magliano) apresenta uma maneira específica de estudar a compreensão da leitura por crianças. Recupera o protocolo de pensado em voz alta como forma de estudo, complementado com questionário.

A resposta de van den Brock enfoca o tornar-se alfabetizado lembrando que muitas são as variáveis que influem no êxito e no fracasso nesta tarefa de desenvolvimento. Destaca que não podem ser ignoradas as diferenças individuais que não podem ser ignoradas na prática educacional. Lembra que as pesquisas que sustentam os dois capítulos anteriores mostram o impacto das diferenças individuais e que as técnicas de ensino individuais a despeito de suas limitações precisam ser implementadas.

A última parte enfoca o desenvolvimento do professor e a avaliação. Au e Asan apresentam um trabalho de alfabetização realizado com crianças oriundas de famílias de baixa renda, de longa duração. Calfu discute a avaliação da alfabetização crítica com ênfase nos instrumentos e técnicas. Toma como fio condutor sua própria trajetória dos anos 50 aos 90. Destaca em relação a cada fase as ocorrências em termos de currículo' instrução e avaliação. Apresenta um quadro-síntese muito interessante. Waltts responde discutindo o desenvolvimento do ensino da alfabetização e da avaliação para todas as crianças enfocando: a relação currículo-instrução; a avaliação e o desenvolvimento docente.

As conclusões são feitas por Pearson que começa com uma síntese excelente sobre as tendências destacando que neste debate retórico entre as várias posições parece haver um Nós e Eles marcante a dificultar uma integração. Lembra que subjacente a este debate há questões filosóficas, políticas e curriculares. Um movimento de unificação se faz necessário e propõe que possivelmente o denominado linguagem total seja a solução. Na perspectiva curricular, a busca da integração e da autenticidade são muito importantes. Da perspectiva filosófica há dificuldades a superar na perspectiva construtivista da compreensão quando os demais membros da comunidade exigem regras de evidência e argumentação como base para evitar o caos da leitura idiossincrática.

Do prisma político é evidente a necessidade de mudança, mas isto implica em decidir quem 
deve mudar o Nós ou Eles (já referidos) o que não é fácil, quando ninguém quer ceder. A proposta da linguagem total é que todas as decisões devem ser tomadas a partir de situações o mais próximo possível das que serão implementadas. Após outras considerações enfoca os princípios a serem considerados na construção de um novo currículo para alfabetização com destaque para: autenticidade de todos os aspectos da instrução, perspectiva otimista do potencial do estudante, o professor como modelo de leitor, controle do ambiente para ajudar o estudante a enfrentar as dificuldades; premiar o controle do estudante, respeito à comunidade e busca por relações.

Fechando o livro aparecem notas de apresentação dos autores, índice de autores e assunto que facilitam a consulta a obra.

Trata-se de livro de grande interesse por seus aspectos científicos, tecnológicos, políticos educacionais e por sua atualidade temática e bibliográfica.

Geraldina Porto Witter

Pontificia Universidade Católica de Campinas 